\title{
Uma rápida emergência do "clima de latência"*
}

\section{Hans Ulrich Gumbrecht}

15 de junho de 1948 foi uma terça-feira clara, mas abafada, na Baviera. O que a Alemanha se tornaria parecia totalmente incerto, o passado da nação pesava como um fardo premente, mas dificilmente mencionado, e ninguém parecia antecipar - talvez poucas pessoas se importassem de fato - que uma semana depois o futuro seria traçado. A primeira página do Süddeutsche Zeitung-Münchner Nachrichten aus Politik, Kultur, Wirtschaft und Sport ${ }^{1}$ parecia muito com o que se parece hoje, exceto pela fotografia em preto e branco (de Carl Zuckmayer, um autor nascido na Alemanha que depois adquirira cidadania americana, com sua mulher e sua filha) e pelo preço da edição, que era de vinte centavos. Cinco textos na metade de cima da página reuniam a configuração política chave do momento, não apenas para a Alemanha. Mas, o jornal fazia isso de uma maneira estranhamente distante. Anunciava-se que todos os preparativos para a reforma monetária nas três zonas ocupadas pelos aliados da Segunda Guerra Mundial estavam terminados e que a definição de uma data exata para a implementação da nova ordem financeira dependia inteiramente das autoridades aliadas. Outro texto cobria um discurso de campanha que o presidente Truman havia feito em Berkeley, Califórnia, clamando aos soviéticos que não se retirassem dos esforços construtivos de assegurar um futuro democrático e unificado para a Alemanha (é uma questão histórica em aberto saber se os aliados ocidentais e a União Soviética não estavam optando por uma separação da Alemanha, embora, por razões de legitimidade política, eles tivessem que responsabilizar uns aos outros). Duas pequenas notas se referiam às hesitaçôes do parlamento francês quanto à ratificação dos primeiros passos políticos em direção à criação de um estado alemão ocidental que os três aliados ocidentais, junto com Holanda, Bélgica e Luxemburgo, haviam decidido treze dias antes, em uma reunião de cúpula em Londres. Finalmente, o general Clay, governador militar norte-americano, foi mencionado, a partir de uma entrevista coletiva, prometendo que os Estados Unidos estavam fazendo todos os esforços possíveis para integrar "uma representação alemã oriental" no novo Estado. Quatro desses cinco textos tinham o estilo neutro típico das agências de notícias (de fato, três vieram da AP, da Dena-Reuter e da UP), mas o artigo escrito pela equipe do Süddeutsche, mesmo que lidasse com a reforma econômica como se fosse assunto de verdadeira preocupação existencial, talvez tenha sido o mais isento de todos eles.

Apenas dois outros textos da primeira página tinham um tom mais vivo, por vezes até agressivo, quando tocavam em pontos que deveriam ter exigido mais tato e reserva pelo lado alemão. Um deles era a ainda famosa coluna no lado esquerdo da primeira página do jornal intitulada Das Streiflicht. ${ }^{2}$ Em 15 de junho de 1948, ela criticava as estratégias com relação à política mundial por parte dos Estados Unidos, especialmente o apoio destes, através de uma legião estrangeira, cuja formação fora aprovada pelo Senado, à fundação de um Estado judeu, tal como havia sido criado no protetorado britânico, há exatos um mês e um dia. Com claros tons antissemitas, Streiflicht ridicularizava sessenta e quatro alemães não-judeus que haviam se apresentado para combater pela causa judia, mas que tinham sido rejei-

\footnotetext{
* O Comitê Editorial agradece a Valdei Lopes de Araújo e a Carlos Fico a oportunidade de oferecer aos leitores de Topoi. Revista de História este artigo, prévia de livro ainda inédito de Hans Ulrich Gumbrecht que tem o título provisório de "Latência. Pós-1945”. Trata-se de uma pesquisa sobre os anos imediatos ao fim da II Grande Guerra. Em um exercício historiográfico que continua as experiências formais presentes no seu livro Em 1926: vivendo no limite do tempo (Record, 1999), o autor analisa um conjunto variado de documentação para reconstruir os climas históricos que emergem no pós-Guerra. Associado a esse esforço, Gumbrecht avança em sua análise/teoria das transformaçóes na experiência da história, tratando de nossa relação com a II Grande Guerra. Rompendo com o vocabulário psicanalítico que tem dominado a reflexão contemporânea sobre a herança da Guerra (repressão, trauma, luto, memória, identidade e narrativa), Gumbrecht propõe novas categorias de análise, notadamente latência, cronótopo e clima histórico.
} 
tados pelas autoridades israelenses: "nós alemães não poderíamos ter desejado mais do que nos afastarmos dessa camada remanescente de agressão militar em nossa sociedade". A mais ampla, entusiástica e autocomplacente matéria, entretanto, fora dedicada à "Segunda Manifestação Internacional da Juventude" que ocorria então em Munique com mil e quatrocentos participantes oriundos de vinte e um países. Entre os convidados de honra, havia trinta ex-prisioneiros de guerra alemães que foram soltos para a ocasião pelas autoridades francesas. Carl Zuckmayer recebeu estrepitosos aplausos por sua garantia de que a juventude alemã não podia ser considerada responsável pelo que acontecera no episódio mais recente de seu passado nacional. No dia seguinte, a Universidade de Munique concederia, como parte da "Manifestação", com todo o meticuloso decoro acadêmico, um doutorado honorário ao romancista francês Jules Romains. Surpreendentemente, uma delegação da Espanha chegara, embora atrasada, ou seja, uma delegação de um país sob governo militar e completamente isolado da ordem política emergente no pós-Guerra, uma vez que havia sido aliado de Hitler. Essa delegação foi recebida com emoção particularmente intensa.

A juventude internacional reunida em Munique, como reportava o jornal, "falou com grande respeito de seus amigos alemães", dos quais queriam ser "bons vizinhos" - e estavam "até mesmo impressionados com a qualidade do suprimento alimentar racionado". Onde e sob quais condições obter comida era naturalmente um assunto de grande interesse para o Süddeutsche Zeitung e seus leitores. Um longo artigo na terceira de quatro páginas discorria sobre a possibilidade, sancionada legalmente, de se receber carne de animais que haviam sido abatidos por motivos de doença (Freibank), ${ }^{3}$ mas fazia isso como que subestimando as necessidades materiais implícitas - descritas em tom irônico - daqueles que formavam a longa fila de mais de três mil pessoas esperando por essa possibilidade. Cultura, assim como comida, parecia ser principalmente uma questão de fornecimento e quantidade. Três programas de cabaré político em Munique foram descritos sob o nome de "Maré alta para os cabarés", junto com várias novas produçôes de dramas clássicos, como os de Lope de Vega e Henri de Montherlant (sem sombra de dúvida, a cultura francesa gozava do mais alto prestígio, tal como sempre havia sido na cultura alemã antes da década de 1930). Havia também a notícia de uma exposição de quadros renascentistas, aberta pelo general Clay na Casa das Artes, composta por pinturas que eram agora devolvidas ao Estado da Bavária pelas autoridades americanas.

Mesmo para um jornal de quatro páginas, a seção de esportes era bastante pequena quando comparada às expectativas atuais. A seção abria com o programa de uma competição de boxe (que deve ter sido o esporte mais popular na Alemanha de então), entre as cidades de Zurique e Munique e que era interpretada e celebrada como um gesto amigável da Suíça pelo fim do banimento de atletas alemães das competições esportivas internacionais. Por contraste, a cobertura de futebol quase tinha um tom de elegia tendo em vista a decadência: "O time de Mannheim, apesar de seu estilo de jogo mais maduro, não conseguiu marcar um único gol; Munique 1860 marcou. Esse fato deve inspirar nossa esperança de que, um dia, seus atacantes, que deixaram tanto a desejar, possam reencontrar sua melhor forma”. Toda a metade de baixo da mesma página estava preenchida por anúncios de emprego: os mais requisitados eram de homens e mulheres com competência em negócios, administração e datilografia, além de "garotas" que trabalhassem como empregadas domésticas. Naquele dia, não havia anúncios de pessoas procurando emprego.

Sem conhecimento adicional sobre os contextos local e histórico, seria impossível para um leitor imaginar que o Süddeutsche de 15 de junho de 1948 fora escrito, impresso e distribuído numa cidade cujas áreas centrais continuavam devastadas pelos bombardeios aéreos; numa cidade que também havia sido a sede oficial do Partido Nacional Socialista dos Trabalhadores Alemães, o partido de Adolf Hitler e Heinrich Himmler, partido que demonstrara à humanidade crimes de uma perfeição tecnológica sem precedentes. Ainda mais difícil seria para o leitor comum encontrar qualquer indicação das mudanças realmente miraculosas (mais do que meramente "dramáticas") à beira das quais a cidade de Munique e o país se encontravam e das quais fariam parte. Parece que as pessoas que sobreviveram à guerra esta- 
vam tão desesperadamente ocupadas sobrevivendo ao novo dia a dia de paz que elas não podiam apreciar seus êxitos recentes, nem avaliar sua própria cegueira. Cercadas por horrores passados e sucessos futuros, a vida naquele dia de verão deve ter parecido tão simples e "normal" quanto On a Slow Boat to China, de Benny Goodman, a música tocada pela rádio norte-americana, American Forces Network.

A distribuição da nova moeda, chamada "marco alemão", começou sob céus chuvosos nas zonas de ocupação americana, inglesa e francesa no domingo de 20 de junho de 1948. Cada cidadão tinha o direito de trocar até quarenta dos velhos Reichsmarks pela mesma quantia da nova moeda, com uma parte adicional de vinte marcos sendo anunciada em agosto. Qualquer quantia maior de dinheiro podia ser trocada numa taxa de cem (moeda velha) para cinco (nova), enquanto a taxa para cheques e poupanças, assim como para pagamentos excepcionais, era de dez para um. Para mais de quatrocentos tipos de mercadorias, as sançôes de racionamento foram suspensas. Apesar de seguidas de medo e de um efetivo aumento na taxa de desemprego, essas medidas desconectaram o país eficientemente de uma dimensão de sua implosão passada e foram o pontapé inicial para o "milagre econômico" que forneceria o tom existencial dominante dos primeiros anos da República Federal da Alemanha.

Com sua rapidez, a reforma econômica ocidental pegou de surpresa a administração soviética da outra parte do país e a obrigou a realizar uma reforma monetária oriental três dias depois, de modo a proteger a zona soviética contra uma enxurrada de velhos Reichsmarks vindos da porção ocidental. Tentando implementar a justiça social por meio de melhores taxas de conversão para aqueles que tinham quantias menores de dinheiro, os princípios por trás da transição econômica oriental eram significativamente diversos daqueles de sua contraparte ocidental. Sistematizando intervençôes prévias ocasionais ao nível de ameaças políticas mundiais, a União Soviética retaliou, um dia depois, em 24 de junho de 1948, interrompendo todas as comunicações por terra, por ferrovias, ou por água, entre as zonas ocidentais da Alemanha e os setores ocidentais de Berlim. O general Clay, apesar de inúmeras dúvidas causadas por motivos logísticos, tecnológicos e, sobretudo, estratégicos - mas apoiado pelas autoridades britânicas -, ordenou imediatamente a criação de uma ponte aérea que ligasse a Alemanha Ocidental a Berlim. Dentro de algumas semanas, 269 aviões britânicos e 314 aviōes norte-americanos realizavam 550 voos diários através de três rotas (desde Frankfurt, Hannover e Hamburgo) para três aeroportos na Berlim Ocidental (Tempelhof, Gatow e, desde dezembro de 1948, Tegel), mantendo o controle sobre os setores ocidentais da antiga capital e assegurando a sobrevivência de sua população. Num intervalo de menos de cem horas, o pós-Guerra terminava e a Guerra Fria, que já havia sido discutida enquanto uma possibilidade e um pesadelo políticos mundiais, tornava-se a nova realidade. Antes do fim do mesmo mês, o Kominform excluiu o Partido Comunista da Iugoslávia sob as acusações de "atitudes antissoviéticas e anti-internacionalistas". Menos de dois meses mais tarde, os primeiros ministros dos países que ocupavam as zonas da Alemanha Ocidental escolheram, surpreendentemente, a pequena cidade universitária de Bonn, próxima a Colônia, como o lugar para os debates em torno a uma nova constituição.

Se aquelas semanas, durante as quais os contornos de uma nova ordem mundial tomavam forma, estavam tão estranhamente indiferentes diante de suas próprias tensões e sequências de ação, os meses finais da Guerra foram um cenário de simultaneidades grotescas e de histeria. Pense-se, por exemplo, naquela assustadora fotografia de abril de 1945 na qual Adolf Hitler, de aparência frágil e parecendo ser bem mais velho que seus cinquenta e seis anos, aperta a mão de garotos uniformizados enfileirados, como se eles fossem soldados de verdade, como se ele ainda possuísse uma autoridade paternal ou militar, como se a guerra não estivesse há muito perdida e como se aqueles garotos pudessem acreditar que havia qualquer propósito em sacrificarem suas vidas. Este "como se" é apenas uma impressão nossa de como certos gestos não se encaixam, de como eles grotescamente não se encaixam no ambiente em que ocor- 
reram, ou este "como se" é antes uma fórmula aproximada, mas inadequada, para a mistura específica de desesperança e cinismo com a qual a estranha justaposição do momento foi vivenciada? É possível que Hitler ainda acreditasse em si mesmo na primavera de 1945; é possível que aqueles garotos ainda confiassem nele? Aqueles alemães que alguns dias após a rendição incondicional foram forçados a andar pelos campos de concentração construídos por seu governo e por seus concidadãos, aqueles alemães foram sinceros quando agiram como se eles nada soubessem sobre esses equipamentos de lentas execuçóes? $\mathrm{O}$ que meus pais pensaram quando eles convidaram seus amigos e parentes, através de cartôes feitos com papel artesanal e escritos com letras góticas, para um jantar de filiação, em 20 de abril de 1945 (aniversário de Hitler, mesmo que eles não estivessem particularmente envolvidos com o Nacional Socialista dos Trabalhadores Alemães), na cidade de Dortmund, nada menos que o lugar onde uma das mais duras batalhas dos últimos meses da Segunda Guerra Mundial havia sido travada até alguns dias antes? Eles não viam problema algum? Passou por suas cabeças que as casas danificadas onde eles estavam dormindo, comendo e fazendo sexo desmentiam o próprio convite formal para sua festa? Ou eles estavam agindo como se nada tivesse ocorrido porque o abismo era demasiadamente profundo para encará-lo? Isso era uma forma de ignorar suas condições de sobrevivência? Estava Hitler - ou qualquer pessoa nas escassas cercanias subterrâneas de seu bunker - realmente convencido, "filosófica" ou "religiosamente" convencido (se é possível utilizar esses advérbios), tal como fingia, de que era um destino justo e necessário que a "raça" alemã fosse submetida, fosse fisicamente destruída e removida da superfície do planeta, uma vez que havia provado ser mais fraca que as outras "raças" e, logo, desmerecia a dominação mundial?

Naturalmente, esses tons agudos vindos dos encontros tardios da guerra desapareceram depois da rendição incondicional de 8 de maio de 1945; mas o "como se" do ignorar agressivamente continuou a ser um hábito dos sobreviventes sob condições de vida que se tornaram piores do que qualquer um havia conseguido antecipar. Essa, ao menos, era a impressão que o jornalista sueco Stig Dagerman, de vinte e três anos, levou consigo quando veio ao país, durante os meses de outono de 1946, com o objetivo de cobrir a situação - provavelmente uma situação histórica sem precedentes - numa série de treze crônicas para seu jornal. Dagerman descreveu, com detalhes impiedosos, o cotidiano de uma família vivendo no andar térreo de um prédio que estava permanentemente alagado. Dizer que essas pessoas estavam vivendo em "condições pré-históricas" não teria sido o bastante. Elas eram como membros de uma civilização moderna violentamente arrastados de volta à vida nas cavernas. Cada passo era um problema; elas haviam aprendido como dormir sem mexer seus corpos e a ameaça de doenças se manifestava em todo lugar. Ao invés de irem para a escola ou terem uma profissão, crianças e adultos procuravam comida, procuravam materiais combustíveis e, ocasionalmente, procuravam roupas numa economia de escambo. Não havia tempo, não havia força, nem mesmo a motivação para pensar sobre quais poderiam ter sido as causas de sua situação. A vida só era possível escapando da morte todos os dias. Os poucos alemães que, por breves momentos, tinham o privilégio de descansar dentro dessa luta, aceitavam sem qualquer protesto o controle absoluto dos aliados sobre o que havia sido "seu" país. Ao mesmo tempo, eles acharam bastante natural contar a Dagerman que eles se sentiam tratados injustamente. Eles estavam sendo honestos quando perguntaram a Dagerman coisas como se Hitler e os doze anos de regime nazista haviam sido realmente culpa sua; ou por que não se levou em conta que os alemães nunca trataram outras naçôes com dureza similar depois de suas próprias vitórias militares?

Diferentemente da situação do tribunal de Nuremberg, os aliados deixaram os advogados alemães que tinham uma "ficha limpa" presidirem os procedimentos legais de desnazificação que se tornaram uma condição inevitável e o limiar para a reentrada da população na vida profissional e civil. Dagerman certamente discordava dessas decisóes logísticas. Embora não culpasse esses novos (e às vezes também velhos) funcionários civis por quaisquer atos de escandalosa injustiça, ou pela tendência a favorecer seus conhecidos, ele percebeu que faltava a eles a paixão e a curiosidade necessárias para detectar e punir os crimes do passado; mais significativamente, para estabelecer uma descontinuidade vis-à-vis ao 
passado, comparável àquela obtida mais tarde no interior do sistema econômico, não menos que um ano e meio depois. Finalmente, Dagerman também observou uma tensão crescente entre duas geraçôes de alemães. Aqueles que tinham entre quinze e trinta anos, muito obviamente culpavam aqueles que tinham a idade de seus irmãos mais velhos, ou de seus pais, ou seja, aqueles que tomaram conta de seu país entre 1933 e 1945, por terem arriscado seu presente e seu futuro. Por outro lado, e de forma ainda mais assombrosa, muitos dos alemães mais velhos acreditavam que os mais jovens haviam falhado em proteger ou até mesmo em libertar a nação da dominação nazista. Acima de tudo, afirmou Dagerman, ninguém se sentia realmente responsável.

Um dos casos em discussão que há muito se tornou famoso e emblemático é a vida do filósofo Martin Heidegger. Por razões que eram biográfica e intelectualmente muitíssimo plausíveis, ele se tornara membro do partido de Hitler no dia $1^{\circ}$ de maio de 1933, dez dias após ter sido eleito, com a aprovação do mesmo Partido, como reitor da Universidade de Freiburg. Bastante cedo, o reitorado de Heidegger deve ter começado a parecer problemático aos olhos dos novos governantes que, até onde se pode dizer, nunca entenderam verdadeiramente a importância de seu trabalho filosófico. Quase exatamente um ano após sua eleição, a demissão que Heidegger pedira foi concedida. Desse momento em diante, ele manteve certa distância da política, até mesmo da política universitária, e chegou mesmo a fazer algumas críticas ocasionais - considerações críticas brandas, deve-se dizer - sobre políticas alemãs correntes, incapazes de preencher a vocação histórica do movimento Nacional Socialista. Mas, ele nunca teve a coragem (e provavelmente nunca a vontade) de abandonar o Partido. No começo de 1947, o leitor e admirador francês de Heidegger, Jean Beaufret, enviou-lhe uma carta pedindo que esclarecesse sua visão particular - e estava implícito: sua "re-visão" particular - acerca do conceito de "Humanismo" no mundo do Pósguerra. A iniciativa de Beaufret foi claramente inspirada pela então - e ainda hoje - famosa palestra intitulada "O existencialismo é um humanismo" ("L'existentialisme est un humanisme"), de Jean-Paul Sartre. A reação de Heidegger, por sua vez, não foi apenas educadamente negativa. No que se tornaria seu primeiro texto publicado após a rendição incondicional da Alemanha, ele desenvolveu uma visão da situação contemporânea da filosofia (do "pensamento", como ele preferia dizer), cujo vazio impiedoso me impacta como um equivalente intelectual da situação material da Alemanha na mesma época.

Ele começa com uma questão retórica que dificilmente atenua o papel de autoridade que está assumindo, em sua conversa com Beaufret:

Você pergunta: "Como dar sentido novamente à palavra 'Humanismo'?” Essa pergunta nasce da intenção de conservar a palavra "Humanismo". Pergunto-me se isto é necessário. Ou a desgraça que expressōes dessa natureza provocam não está ainda suficientemente visível?

Nunca havia sido do feitio de Heidegger admitir que ele desenvolvera - na verdade, revisara - posicionamentos filosóficos em reação às mudanças em seu ambiente. E mesmo assim as palavras "não ainda" indicam que sua posição é assumida a partir das influências de seu presente devastador. Sua "Carta sobre o Humanismo" é, acima de tudo, uma crítica do antropocentrismo tradicional e, mais especificamente, uma crítica que pretende sublinhar que, independentemente do que seja importante acerca do Dasein ("existência humana"), só o será em relação ao "desvelamento do Ser" como um destino maior (Geschick), no qual o Dasein tem de desempenhar um papel, sem nunca ser capaz de compreender por que e como seu papel importa. Como se ele nunca tivesse desejado ser o que ele programática e publicamente fora, ao menos durante seu tempo como reitor em Freiburg, isto é, um filósofo que compreendia a nacionalidade (nationhood) como quadro existencial decisivo, Heidegger agora rejeita tanto o nacionalismo quanto o internacionalismo como configuraçóes inadequadas dentro da história do Ser:

Diante de sua expatriação intrínseca, o futuro destino do homem mostra-se ao pensamento histórico-ontológico no fato de ele achar um caminho para a verdade do ser e empreender a marcha para este encontrar. Cada nacionalismo é, do ponto de vista metafísico, um antropologismo e, como tal, subjetivismo. O nacionalismo não pode ser superado pelo simples internacionalismo, mas apenas ampliado e transformado em 
sistema. O nacionalismo conduz tão pouco a humanitas assim como o individualismo através do coletivismo ahistórico. Este último é a subjetividade do homem na totalidade. Ele realiza sua incondicional autoafirmação. Esta não se deixa reconduzir às suas origens. Ela nem se deixa experimentar, de modo suficiente, através de um pensamento que não radicaliza a mediação. Expulso da verdade do ser, o homem gira, por toda parte, em torno de si mesmo, como animal rationale.

"Expatriação", como uma metáfora, transformara o destino daqueles milhões de alemães que perderam suas vidas e abrigos na antiga periferia oriental do país - mas, também a destruição das cidades alemãs - numa concretização do que o diagnóstico de Heidegger identificara como a verdadeira crise do momento: para ele, era a incapacidade, talvez até mesmo a inaptidão, das geraçôes contemporâneas de captarem o destino, o Ge-Schick, isto é, o lugar existencial que o desvelamento do Ser lhes assinalara e reservara. Suas premissas ontológico-existenciais nunca devem ter soado mais convincentes que neste tempo de superior humildade - também para a filosofia:

Chegou a hora de desacostumar-se de supervalorizar a Filosofia e por isso fazer exigências demasiadas. $\mathrm{Na}$ atual precariedade do mundo, é necessário menos Filosofia, mas mais desvelo no pensar; menos literatura e mais cultivo da letra.

O pensamento futuro não é mais Filosofia, porque pensa mais originariamente que a Metafísica, cujo nome diz o mesmo. Mas, o pensar futuro também não pode esquecer, como exigia Hegel, o nome do "amor pela sabedoria" para converter-se a própria sabedoria na forma do saber absoluto. O pensamento se encontra em queda para a pobreza de sua essência provisória. O pensar recolhe a linguagem para junto do simples dizer. A linguagem é, assim, a linguagem do ser, como as nuvens são as nuvens do céu. Com seu dizer, o pensar abre sulcos invisíveis na linguagem. Eles são mais invisíveis que os sulcos que o camponês, a passo lento, traça pelo campo.

Em 1947, quando Martin Heidegger escreveu essas frases sobre a "precariedade do mundo" e a "pobreza" da filosofia, usando imagens retiradas do mundo da agricultura, os estoques de comida da população alemã haviam se tornado tão baixos que sua condição ameaçava a própria sobrevivência. Após um inverno estranhamente frio e um seco verão, a média de calorias diárias disponíveis para os adultos havia caído das três mil, de antes da guerra, para novecentas - ou seja, para seiscentos a menos que o limite de mil e quinhentas que os aliados haviam estipulado. Ao mesmo tempo a taxa de divórcios estava subindo de 8,9 a cada dez mil pessoas em 1939 para 18 a cada dez mil em 1948.

As coisas mudaram no início do verão de 1948, mas muito poucos alemães falaram alguma vez sobre a percepção das mudanças que vinham. Era porque sua situação havia se tornado tão ruim, tão permanentemente ruim, como dava a impressão, que a capacidade de imaginar e até mesmo de ter saudade de uma vida diferente se perdera? Era literalmente difícil retornar da pré-história? Na edição de maio de 1948 da revista Die Wandlung, ${ }^{4}$ influente periódico mensal de impressionantes qualidades intelectuais e determinações democráticas, editado por Dolf Sternberger, Karl Jaspers, Marie Luise Kaschnitz e Alfred Weber, se entrevia algumas pálidas expressões de esperança: "Com mais condições meteorológicas normais e um fornecimento um pouco melhor de fertilizantes, há uma séria esperança de que a colheita melhore e possa talvez prover entre mil e duzentas e mil e trezentas calorias por dia, ao contrário das treze mil do último mês”. Ao mesmo tempo, argumentava-se com uma visão sistemática e uma perspectiva de longo prazo que o retorno à comunidade econômica internacional era necessário para a Alemanha e atendia aos interesses de todos os países. Dolf Sternberger observou que o papel do Estadonação como unidade chave no jogo de poder político estava agora desaparecendo para ser substituído por uma tensão entre o que o autor chamava "dois partidos", nomeadamente os blocos americano e soviético. Por fim, Adolf Arndt, um jurista e futuro representante na Câmara, contribuiu com a mais brilhante e filosoficamente complexa peça publicada naquela edição de Die Wandlung. Da mesma forma que Heidegger, ele argumentou que a tradicional "crença na Humanidade" havia sido perdida na crise 
atual, junto com a convicção de que os homens estavam suficientemente equipados para resolver, sem quaisquer crises e contratempos, todos os problemas com os quais eles jamais seriam desafiados. Como exemplo contemporâneo, ele mencionou a dupla transição, que considerava não estar totalmente completada no momento presente, do "Estado sagrado" ("Sakralstaat") em direção ao "Estado social” e, do "Estado nacional", em direção à ordem universal. Nessa situação, notou Arndt, um intenso - e compreensível - anseio por valores éticos e religiosos substanciais emergia, um anseio por posições às quais se agarrar e através das quais encontrar orientação. Seu próprio argumento decisivo era, ao contrário, que apenas um quadro de referências legal que renunciasse a essas premissas substanciais seria flexível o bastante para fazer a paz duradoura possível num ambiente de esmagadora complexidade. Em outras palavras: renunciar à busca por soluçóes imediatas aparecia como a condição para a sobrevivência e para o sucesso a médio prazo.

Menos de cinco anos depois, os problemas que a classe média alemã, que meus pais integravam, estava enfrentando pareciam muito diferentes. Eu nunca os ouvira falar acerca de sua festa de filiação dezoito dias antes da rendição incondicional. Meu pai havia sido um prisioneiro de guerra dos americanos por cerca de um ano, num campo chamado "Oklahoma”, não longe da cidade francesa de Reims, e se as fotografias que ele levou para casa não mentem, ele passou esse tempo em condiçôes quase que confortáveis. Quando meu pai foi solto (às vezes ele dizia que havia escapado), o comandante do campo, surpreendentemente, escreveu para ele uma carta de recomendação, "a quem interessar possa”, louvando a assistência que ele havia sido capaz de oferecer a seus colegas prisioneiros, como estudante de medicina com uma formação quase terminada. Meus pais se casaram em maio de 1947, alguns meses antes que a fome pós-Guerra chegasse ao seu auge e, compreensivelmente, a maior parte de suas memórias daquela época tratava de quantidades excessivas de comida. Eles tiveram sorte o bastante para encontrar emprego no hospital universitário da minha cidade natal, que os bombardeios aliados transformaram na segunda cidade mais destruída da Europa (não por coincidência, ela é cidade-irmã de Nagasaki, no Japão). Com dois salários de cerca de duzentos marcos, eles podiam manter o luxo de contratarem uma babá para mim. Seu nome era Helgard, ela era a filha de um trabalhador ferroviário e eu ainda me lembro dela como muito bonita e muito mais carinhosa que minha mãe. Um dia, contudo, minha mãe me contou que Helgard não voltaria novamente. "Ela tornou-se má" ("sie is bose geworden"), disse minha mãe, sem querer fornecer quaisquer detalhes adicionais ou explicações. Helgard foi substituída por uma freira com um véu engomado e que me fazia ficar de joelhos (para rezar, eu creio) antes do café da manhã. A primeira pessoa da qual eu senti falta foi Helgard e, uma noite, no pequeno escritório no hospital onde estávamos vivendo, escutei meus pais explicando a um amigo as verdadeiras razões pelas quais ela havia sido dispensada: "Ela está andando com existencialistas", eles disseram (mais precisamente: "sie verkehrt in Existentialistenkellern"). ${ }^{5}$ É claro que eu não fazia a menor ideia do que eram os "existencialistas" e, menos ainda, de porque eles desejariam passar suas vidas em celas ("Kellern") - e meus pais médicos provavelmente não sabiam muito mais acerca da última influência francesa sobre o espírito alemão. Mas, eles rápida e seguramente retornaram a um mundo onde se entendia que o próprio estilo de vida de classe média de alguém necessitava ser protegido por altos muros contra o que quer que fosse considerado excêntrico. Ocasionalmente eles ainda mencionavam "a Guerra", mas eu a considerava como uma espécie de horizonte vago, algo que de toda maneira acontecera antes de eu nascer, não necessariamente algo ruim. Eu a associei com muitas das ruínas da minha cidade natal, mas eu não conhecia cidades sem ruínas e logo descobriria que era muito divertido nelas brincar.

Deve ter sido por volta de 1950, quando meu pai ficou em Munique por cerca de meio ano fazendo residência para adquirir a especialização em urologia, então o ramo mais atualizado da medicina, que de lá mandou cartas com desenhos e recheadas com cartões-postais para seu filhinho. Em alguns deles, algumas esquinas da cidade se pareciam exatamente como hoje, ou seja, como a capital de uma 
pequena monarquia do século XIX, com um ar opulento de dinheiro velho e grandes carros, sobretudo Mercedes meticulosamente preservados, que tinham até mesmo o tamanho monumental dos carros britânicos e norte-americanos. Noutras fotografias, Munique é um grande canteiro de obras, ocupado por um grande tráfego de carros menores, Volkswagen principalmente e alguns Opel, mas também caminhões com terra e outros materiais de construção. As poucas pessoas que não estão dirigindo nessas fotos parecem estar apressadas. Eu também encontrei um cartão-postal colorido, datado de 1955, que de alguma forma ilustra o futuro em relação às imagens na correspondência de meu pai. Novamente se trata de carros, mostrando de forma orgulhosa um posto de gasolina nomeadamente "grande" ("GrossGarage Nymphenburg"), em Nymphenburg, um elegante bairro residencial cujo nome provém de um castelo de verão construído no começo do século XVIII. A “Gross-Garage” na verdade não é tão grande - mas parece estar orgulhosa de si mesma. Apenas um carro, uma limusine Mercedes preta, provavelmente tipo 220, está estacionada como se estivesse abastecendo. Ela tem o chassi mais compacto e quase quadrangular da primeira geração de modelos Mercedes do pós-Guerra, além da listra branca em seus pneus pretos que fora adotada dos Estados Unidos como sinal de distinção e elegância. Do lado de fora, mas bem em frente à garagem, está uma caminhonete da Volkswagen meticulosamente pintada de vermelho e preto. Na sua frente, o Volkswagen preto e vermelho mostra os sinais de um seguro automotivo (deve ser o "DAS", isto é, "Deutscher Automobil Schutz") e do famoso ADAC, significando "Allgemeiner Deutscher Automobil-Club". Há duas estreitas capas em cima de seus faróis, pensadas provavelmente para reduzir quaisquer efeitos agressivos de sua luz. Mas, uma vez que as capas também se parecem com sobrancelhas, elas dão à caminhonete da Volkswagen uma face tímida mas amigável. $\mathrm{O}$ mundo da Gross-Garage é calmo, pacífico e satisfeito consigo mesmo. A não ser que a fotografia tenha sido realmente tirada num domingo, deve ser de um tempo em que todo dia queria ser um domingo.

Talvez, inesperadamente, esse clima de contenção na metade do século XX não tenha sido exclusivamente alemão, não tenha sido nem mesmo específico - como talvez se possa pensar - àqueles países que participaram na Guerra. Eu tenho alguns cartôes-postais de 1948 que encontrei num mercado de pulgas em Lisboa. Todos eles são fotos pessoais em formato de cartão-postal, feitas para serem enviadas aos amigos, parentes e entes queridos. Jovens cuidadosamente arrumados enviavam seus retratos preto e branco para amigos e parentes com nomes femininos, sempre adicionando suas "saudações" e frequentemente dizendo algo como "isso é para que se lembrem como eles eram" num dia específico. Tão carregadas de desejos e sonhos quanto essas fotos devem ter sido, não há nunca ambiguidade alguma em sua linguagem, muito menos qualquer piada ou qualquer coisa audaciosa.

Eu também tenho a foto de uma jovem família portuguesa. A mãe é tão bonita quanto qualquer estrela do cinema da época poderia ter sido - como Rita Hayworth, mas com uma pele mais escura. Ela tem uma face perfeitamente simétrica que é delicada, ainda que os ossos lhe determinem a forma, com exceção do arco de seus lábios que forma um remoto sorriso. $\mathrm{O}$ visual do pai é impecável e, sem qualquer dúvida, caro. Ele não é necessariamente mais velho que sua esposa, mas parece desejoso de aparentar seriedade, produzindo o efeito de um homem que parece se sentir desconfortável quando não está usando terno e gravata. Mas seu corpo é rechonchudo, como o de uma criança feia ou o de um idoso que, devido ao sobrepeso, não consegue mais caminhar. Seus braços são curtos, sua pele é caída e seus lábios estão pressionados juntos, como se estivessem prendendo uma palavra que não pode escapar. Ao passo que é difícil imaginar que alguém pudesse gostar dele “à primeira vista”, a questão é se alguém poderia confiar nele. Ou, talvez, de modo mais adequado: ele é demasiadamente fraco e infeliz para seu status, ou ele tem realmente o potencial de ser perigoso? Entre a bela mãe e o gordo e misterioso pai está, sentada num banco, a filha de ambos, que deve ter três anos de idade. Ela tem um elaborado vestido quadriculado, ao estilo de Shirley Temple, ou até mesmo no estilo que as crianças da aristocracia britânica deviam usar na época. Está claro que, um dia, o rosto da garota será similar ao de seu pai - mas, is- 
so não a impede de parecer, ainda, o que hoje chamaríamos de "bonitinha" ou, como alguém na época pode ter dito, "parece um anjinho barroco". Desde que vi e comprei esse cartão-postal, pensei que havia nele uma história, não uma história que alguém pudesse inventar; deve ser uma história verdadeira, precisa e, talvez, dolorosa - mas, uma história que nunca se permitirá ser contada.

Ora, há algo que possa (ou deva) ser importante para nós acerca daquele tempo, no meio do século passado, uns bons sessenta anos atrás, que fosse tão reticente - em tantas maneiras - sobre o que então possa ter sido importante? Uma boa maneira de chegar perto de uma resposta é comparar a época que se segue a 1945 com a época, menos de trinta anos antes, que se seguiu à primeira guerra chamada "Guerra Mundial". O momento do primeiro pós-Guerra de começos do século XX foi vivido como um momento de profunda depressão, não apenas pelos intelectuais. Se os dias de mobilização militar por toda a Europa no começo de agosto de 1914 foram uma orgia de confiança patriótica, havia também um ar de sombria seriedade nos rostos daqueles que, em novembro de 1918, voltaram das trincheiras, fossem vitoriosos fossem derrotados. A partir das fotos e das filmagens que conhecemos, parece que o mundo envelhecera décadas em apenas quatro anos. A busca desesperada por um novo chão estável sobre o qual basear a nova vida, uma busca que tem uma afinidade com os traços de desespero que vimos no texto de Martin Heidegger de 1947, transformara-se numa urgência que permeava todo grupo social após 1948. A biografia de Ludwig Wittgenstein é um caso particularmente dramático, ainda que bastante típico. Ele quis iniciar uma vida nova, bem literalmente, após a derrota e o fim do Império Austro-Húngaro, doando sua grande fortuna e mudando o foco de seu interesse intelectual da engenharia para a filosofia.

Mas, o que tinha sido a incisiva experiência vivida na Guerra que fez com que se alastrasse esse sentimento de que qualquer simples continuação da vida seria impossível? Foi a surpresa, em ambos os lados, durante os primeiros meses do conflito militar, de que um triunfo fácil, seguindo o antigo e até cavalheiresco (ou, ao menos, napoleônico) estilo de lutar, não estava mais disponível. A paralisia de uma guerra de trincheiras com seus sempre pequenos, mas custosos avanços tornara-se o novo horizonte da guerra. Com o desenvolvimento acelerado da tecnologia militar, contudo, com a metralhadora, a aviação e os ataques a gás, uma frustração existencial muito mais profunda começou a aparecer. Essa guerra não era mais uma situação existencial na qual a bravura individual ou o gênio pudessem fazer diferença. Era uma guerra a ser decidida pela quantidade e eficiência do "material", por quem pudesse se permitir o sacrifício de mais centenas de milhares de vidas e pela produção industrial de cada retaguarda civil. Em reação, novas ideologias, sobretudo o comunismo e o fascismo, se estabeleceram na esfera pública, visando afirmar e definir o significado das vidas coletiva e individual na base de valores que se diziam novos.

No que tange à profundidade e extensão de seu poder destrutivo, a Segunda Guerra Mundial faria a Primeira Guerra Mundial parecer pequena - mas, curiosamente e por contraste, dificilmente estimulou qualquer iniciativa, nem mesmo talvez a necessidade de se repensar a existência humana. É claro que houve algumas reações intelectuais, só que elas não pareciam se encaixar no clima dos anos pós1945, de modo que alguns livros importantes como, por exemplo, a Dialética do Esclarecimento, de Max Horkheimer e Theodor W. Adorno, somente causaram real impacto várias décadas depois. Como eu disse antes, o contraste entre as ressonâncias da guerra, no pós-1945 e no pós-1918, inverteram os diferentes graus de devastação que elas trouxeram. Apenas a segunda guerra fora uma "guerra mundial" no que se refere à geografia de sua ação militar. As estimativas para o número total de mortes que a Guerra causou imediatamente são bastante variáveis, mas uma comparação, exposta no Musée de l'Armée, em Paris, dá a forte impressão da proporção: a nação mais afetada durante a Primeira Guerra Mundial foi a França, com 1,37 milhão de vítimas, contra 26,6 milhões de cidadãos soviéticos que morreram durante a Segunda Guerra Mundial. Não há equivalente na Primeira Guerra Mundial para os mais de seis milhões de vidas sacrificadas em campos de concentração alemães, entre 1939 e 1945, e para o desconhe- 
cido, mas certamente ainda maior número de mulheres, crianças e homens que morreram em circunstâncias similares na União Soviética, no Japão e em alguns outros países.

A diferença essencial, entretanto, a diferença que faz as duas guerras verdadeiramente incomparáveis, antropologicamente, por assim dizer, não pode ser expressa quantitativamente: é a fria perfeição na industrialização da morte desenvolvida pela SS alemã e é o limiar que fora atravessado pela imaginação de autoextinção nacional e, até mesmo, a autoextinção da humanidade, com a qual os Estadosmaiores japoneses e alemães começaram a se entreter assim que perceberam que a Guerra estava perdida para eles. Desde 6 de agosto de 1945, desde a primeira detonação de uma bomba nuclear sobre uma cidade, essa imaginação se tornara uma possibilidade técnica concreta e sempre disponível, a qual nós nunca seremos capazes de esquecer. Nós sabemos - mais a partir de seus rostos perpetuados em um punhado de fotografias, do que por meio de suas palavras - que aqueles homens e mulheres que estavam presentes e que sobreviveram ao momento de Hiroshima acreditavam que aquele era o começo do fim do mundo - e nunca haverá futuro o bastante para provar que eles estavam errados.

Mas, de novo, o que é isso sobre o qual ainda não se falou acerca desses anos; o que é essa urgência de escrever mais um livro sobre eles? Creio que seja sobre o impacto da destruição irreversível e sobre a impressão de que esse impacto, depois de estar silenciosamente presente por um curto período de tempo após a Guerra, rapidamente desapareceu. Esse impacto esteve presente não apenas naquelas nações que participaram na Guerra, mas provavelmente por todo o mundo. A edição da revista Life, de 24 de dezembro de 1945, me faz pensar que o Natal daquele ano talvez tenha sido o momento, relativamente cedo, no qual o impacto da destruição irreversível desapareceu nos Estados Unidos. As páginas de $L i$ $f e$ estão cheias de matérias e fotografias que mostram um mundo retornando ao que supostamente ele sempre fora. Uma longa matéria intitula-se "Lavrador japonês: ele volta da guerra para seu antigo padrão de vida em sua aldeia" e isso continua com outros subtítulos, como: "Soldado considera banha e colheita bastante boas apesar de fracasso da produção de trigo"; "Ele ainda observa os arraigados ritos xintoístas" e "A aldeia de Harada é frugal, trabalhadora e intocada pela guerra". O desastre e as feridas de Hiroshima e Nagasaki não aparecem. Pelo contrário, há um anúncio das "câmeras premiadas Graflex" com uma fotografia, feita por um membro da marinha dos Estados Unidos, de uma explosão do Vesúvio que mostra uma nuvem em formato de cogumelo similar àquele que associamos, desde Hiroshima, com armas nucleares. Outra fotografia, que preenche meia página, mostra três belas jovens, vestidas na última moda, sentadas num sofá lado a lado, cada uma, com seu bebê, como uma escultura estranhamente simétrica. Todas as três olham para a esquerda e têm a perna esquerda cruzada por sobre a perna direita. A legenda diz:

Três irmãs mais velhas dão mamadeiras para suas três jovens crianças. Da esquerda para a direita: Jeanne, 22, com o filho Joe; Myrra Lee, 23, com o filho John; e Betty, 25, com a filha Julia. Os maridos de Jeanne e Myrra Lee estão inativos e compareceram às celebrações de Natal. $\mathrm{O}$ marido de Jeanne era um operador de rádio da Oitava Força Aérea com vinte e sete missōes. O de Myrra Lee era um operário naval de segunda classe que passou vinte e seis meses em serviço no mar. O marido de Betty desapareceu em combate.

A simetria espacial dessas três belas jovens mulheres com seus bebês capta a assimetria existencial entre, de um lado, Jeanne e Myrra Lee, cujos maridos voltaram da Guerra, e, de outro, Betty, cujo marido está desaparecido. Alguns especialistas argumentaram que, no Japão, um nível semelhante de assimilação não foi alcançado antes de 1964, o ano das Olimpíadas de Tóquio. Quanto aos efeitos dessa queda em latência, Peter Sloterdijk argumentou, com relação ao período pós-Segunda Guerra Mundial na França e na Alemanha, que uma obsessiva fascinação mútua entre esses dois países começou então finalmente a desaparecer, depois de ter produzido, tanto admiração excessiva, quanto guerras cruéis por dois séculos. Como pedra angular da União Europeia, a assim chamada "amizade" franco-alemã se sustentaria, como condição, na emergência de um desinteresse mútuo. 
Eu não quero usar a palavra "repressão" para o que estava acontecendo na década que se seguiu a 1945. Afinal, o que teria sido mais fácil para a revista Life que meramente não documentar - ou "reprimir" - o destino de Betty? Mais do que ser "reprimido", o impacto da destruição irreversível dos tempos da guerra desapareceu, como se tivesse entrado em um quieto e novo mundo. Os fatos não desapareceram, mas sim seu impacto e sua ressonância. E conforme o impacto da destruição irreversível caiu no esquecimento, um sentimento de latência rapidamente emergiu para se estabelecer (há uma leve impressão de paradoxo ligada ao duplo movimento de um efeito desaparecendo em latência e, ao mesmo tempo, um certo clima emergindo). Por "latência", quero indicar a situação que o historiador holandês Eelco Runia definiu como "presença”. Runia ilustra seu conceito utilizando o passageiro clandestino como metáfora. Numa situação de latência e, sobretudo na presença de um clandestino, nós estamos certos de que existe algo lá que não conseguimos apreender - e que esse "algo" tem uma articulação material; e, portanto, requer espaço. Obviamente, nós não sabemos onde aquilo que está latente pode estar. Como nós não apenas não sabemos onde o que é latente está, assim como não sabemos o que ou quem é latente, nós não temos garantias de que possamos reconhecê-lo se ele se mostrar. É claro que o que está latente pode passar por mudanças enquanto permanece inapreensível. Por exemplo, clandestinos não estão isentos de ação. Mais importante: nós não temos razão - ao menos não razão sistemática - para acreditar que o que se tornou latente vá se mostrar algum dia ou ser completamente esquecido.

Nenhum "método" ou procedimento padrão existe, muito menos qualquer tipo de "interpretação" que possa nos ajudar a recuperar o que caiu em latência. Pois para se tornar acessível à interpretação, isto é, à identificação de um significado que parece subjazer à superfície, o latente teria de adotar a forma de um "conteúdo proposicional", o que por vezes é possível - mas é improvável no geral. Mas, como podemos ter tanta certeza de que algo latente está "lá” se não está disponível para nós? Quando folheio essas pacíficas e ordenadas revistas do pós-Guerra, eu me assombro com a violência que frequentemente aparece em suas propagandas. Como a explosão do Vesúvio, com a nuvem em forma de cogumelo em cima. Essas propagandas mostram como a suprema qualidade das lâminas de barbear é destacada ao passarem suavemente por sobre a delicada pele das bochechas de um neném. Em representações ao estilo de cartoons da vida conjugal, maridos batem alegremente em suas mulheres porque elas não conseguiram passar um café suficientemente forte ou porque se esqueceram de acordá-los. Parece também haver uma obsessão com homens agitados de forma patológica que precisam urgentemente de medicação.

Algo como um nervosismo violento irrita os mundos de latência pós-Guerra. Quero usar a palavra alemã "Stimmung" para caracterizar como nós podemos perceber aquilo que caiu em latência. "Stimmung" é normal e corretamente traduzida por "disposição" ou, como uma metáfora, por "clima" e "atmosfera". O que as metáforas "clima" e "atmosfera" compartilham com a palavra "Stimmung", cuja raiz alemã é "Stimme" ("voz", em alemão), é que elas sugerem a presença de um toque material - talvez o mais leve toque material possível - sobre o corpo de quem quer que perceba uma disposição, um clima, uma atmosfera, ou uma "Stimmung". Tempo, vozes e música todos têm um impacto físico, ainda que invisível sobre nós. É um toque físico que nós associamos com alguns sentimentos “interiores”. Toni Morrison descreveu o lado interior da "disposição" como um paradoxo, isto é, como "ser tocado por dentro". As imagens de lâminas de barbear sobre bochechas de nenéns, de maridos violentos, de avós agitados na publicidade pós-1945, nos deixam fisicamente desconfortáveis, conforme elas nos despertam sentimentos internos de desconforto para os quais nós não temos conceitos. Nenhum "método", porém, nos "levará" de uma "disposição" específica em direção ao que é latente e de cuja presença nós estamos seguros, ainda que não conheçamos sua identidade; não há maneira de isolar o que é latente. Mas, por que então concentrar-se em "disposições" do passado? Uma razão é que isso nos permite imergir, com nossa imaginação, em situações do passado, quase materialmente (por exemplo, quando escutamos música antiga ou vemos fotografias velhas), levando-nos para perto - bastante literalmente - do passado. Ao mesmo tempo, capturar "disposições" pode nos encorajar a lançar, por assim dizer, pode nos inspirar a arriscar - sob a impressão de uma "disposição" - hipóteses sobre o que o latente pode ser. 
Menos de dois anos atrás, quando falei com um bom amigo acerca da urgência, então quase estranha para mim, de escrever sobre os anos do pós-1945, ele disse, sem qualquer hesitação, dúvida, e nem mesmo em tom de pergunta, que a tragicomédia de Samuel Beckett, Esperando Godot, encenada pela primeira vez no Théàtre de Babylon em Paris, durante a temporada 1952/1953, precisava ser o centro de Latência. Pós-1945. Eu nunca havia pensado sobre essa necessidade, mas ela imediatamente se tornou uma daquelas certezas que, retrospectivamente, nos fazem duvidar que não haja existido em algum momento. Esperando Godot não é uma representação da latência pós-Segunda Guerra Mundial; a peça, ao contrário, é sua máxima condensação, uma vez que emerge de um oceano de latência. Pois não passa pelas cabeças de Estragon, ou Vladimir, que Godot, a quem nunca viram, possa ser um fantasma ou simplesmente não exista. Tal como seu mundo aparece, a existência de Godot é uma certeza da qual eles às vezes lembram um ao outro e cujas consequências eles ocasionalmente mencionam. Sobretudo, o latente Godot os obriga a permanecer onde estão:

ESTRAGON: Lugar encantador. [Ele se vira, avança para a frente do palco, para, encarando o auditório] Possibilidades inspiradoras. [Volta-se para Vladimir] Vamos.

VLADIMIR: Não podemos.

ESTRAGON: Por que não?

VLADIMIR: Nós estamos esperando Godot.

ESTRAGON: [Aflito]. Ah! [Pausa] Você tem certeza de que era aqui?

É com o "grande Deus" Godot (inglês com um sufixo francês: "God-ot"), como com o Deus da Idade Média, cuja presença real ninguém questionava, mesmo que ninguém nunca pudesse estar completamente certo a respeito de onde ele se manifestaria. Essa situação não se modifica até o final da tragicomédia:

ESTRAGON: Ah sim, vamos para longe daqui.

VLADIMIR: Não podemos.

ESTRAGON: Por que não?

VLADIMIR: Nós vamos ter de voltar amanhã.

ESTRAGON: Para quê?

VLADIMIR: Para esperar Godot.

ESTRAGON: Ah! [Silêncio] Ele não veio?

Já que eles nunca o viram, Vladimir e Estragon não têm nenhuma certeza de que, tal como tudo que está latente, eles reconheceriam Godot, caso este o encarasse. Pode ser então que Pozzo, com quem falam duas vezes, seja Godot:

ESTRAGON: Você está sonhando com isso. [Pausa.] Vamos. Não podemos. Ah! [Pausa.] Você tem certeza de que não era ele?

VLADIMIR: Quem?

ESTRAGON: Godot?

VLADIMIR: Mas quem?

ESTRAGON: Pozzo.

VLADIMIR: De forma alguma! [Com menos certeza]. De forma alguma! [Com ainda menos certeza]. De forma alguma!

Há um efeito de latência em Esperando Godot que não ficou claro senão quando eu estava descrevendo a latência pós-Segunda Guerra Mundial. Esperar Godot, que não aparece, congela o tempo, e o tempo congelado faz todo progresso e, por extensão, todo tipo de ação, impossível - já que toda "ação" necessita de um futuro para se transformar, de uma motivação, em uma realidade. A peça de Beckett termina de modo célebre com as seguintes palavras: "VLADIMIR: Então? Vamos? - ESTRAGON: 
Sim, vamos. - [Eles não se mexem]”. Num tempo que não se desenrola, eles não podem avançar, eles não podem agir e eles não podem nem mesmo se matar. Como com um casal velho e rabugento, nada realmente muda entre Estragon e Vladimir. De uma forma parecida, a relação senhor/escravo de Pozzo e Lucky parece não ser passível de transformação. Quando Estragon e Vladimir conhecem Pozzo e Lucky pela segunda vez, Pozzo procura um papel de submissão em relação a Vladimir e Estragon ("ser igual", com relação a alguém, não parece ser uma opção para ele), mas isso não tem nenhuma consequência para a relação de poder entre Pozzo e Lucky, o qual continua sendo o animal e escravo de seu mestre. Fazer o esforço de pensar tampouco muda alguma coisa; acima de tudo, pensar ajuda no processo de se chegar perto da latência de Godot e da possível chegada deste. Mas, quando Lucky "pensa”, tal gesto faz Estragon e Vladimir mudarem do tédio para o "protesto violento", pois o que a peça e seus protagonistas chamam de "pensar" é um estado de alta agitação que não leva a lugar nenhum.

Não irei pular para a conclusão de que a queda em latência do impacto da Guerra fez o tempo do pós-Guerra se congelar. Apenas direi que a expectativa e a esperança carregadas pelos momentos subsequentes, durante as últimas seis décadas e meia, de que algo latente viesse à tona e se mostrasse, dessa forma permitindo à humanidade finalmente escapar à longa sombra de uma "disposição", cujas fontes permanecem não identificadas, que essa expectativa e esperança por um tipo específico de mudança nunca foi realizada. Nossa situação é como a de Vladimir na peça de Beckett: "Bem, suponho que, no final, eu vou me levantar sozinho. [Ele tenta, falha] Quando o tempo se completar". Quem viu o final do filme de Rainer Werner Fassbinder, O casamento de Maria Braun, sabe que a primeira ilusão alemã pós-Guerra de que "a completude do tempo tinha chegado", ironicamente, estava relacionada a um jogo de futebol. Eu tinha apenas seis anos e três semanas quando, no dia 4 de julho de 1954, escutei com meus pais e com alguns de seus amigos a cobertura de rádio da final da Copa do Mundo daquele ano na qual, de forma sensacional, a Alemanha venceu o time húngaro, claramente superior, por 3 a 2 . No filme de Fassbinder, a voz triunfante de Herbert Zimmermann, o locutor, gritando "Acabou, acabou, acabou, a Alemanha é campeã mundial!” (“Aus, aus, aus, Deustchland ist Weltmeister?') se sobrepõe ao estrondo de uma explosão de gás; e essa explosão destrói a vila que se tornara o monumento de fortuna e esperança acumuladas por Maria Braun durante os anos do pós-Guerra - acumuladas para que passasse uma vida plena com seu marido.

No novo apartamento de dois quartos da minha família, a voz de Zimmermann, como se fosse uma ordem militar, fez os adultos se levantarem e cantarem uma canção solene que eu nunca ouvira antes, provavelmente a primeira estrofe do hino nacional alemão, que começa com as palavras chauvinistas "Alemanha, Alemanha acima de tudo, acima de tudo no mundo" ("Deutschland, Deutschland ueber alles, ueber alles in der Welt"), e que havia sido banido da esfera pública pela lei. Minha vaga, porém correta impressão de que algo importante mudara naquele momento, foi confirmada pelo que logo se tornou o slogan autocongratulatório de "Nós voltamos a ser respeitáveis" (“Wir sind wieder wer"). Entretanto, embora a respeitabilidade no futebol, junto com o notório "milagre" da economia alemã, durante os anos 1950, tenha ajudado o país a esquecer o que ele não fora capaz de lembrar, ela não significou, contudo, que a latência pós-Guerra tenha chegado ao fim.

Uma década e meia, mais tarde, o sentimento intransitivo de falta de sentido se articulou no rosto de James Dean e logo se transformaria na interrogação, acusação e revolta mais agressivas contra as gerações mais velhas que aconteceram por todo (e talvez não só) mundo ocidental, ao estilo de 1968. Em muitos países diferentes, minha geração acreditou que a implacável compilação de todos os crimes cometidos por nossos próprios pais e ancestrais, que tal transparência nos libertaria de uma atmosfera de contenção e hipocrisia. Na Europa, ao menos, 1968 talvez tenha levemente trazido à superfície o efeito de uma revolução cultural que produziu maior transparência histórica, um grau mais alto de solidariedade social e uma tolerância excessivamente generosa com relação ao lado socialista da Guerra Fria. 
Talvez nós tenhamos, então, entrado num diferente período de quieta e pacífica latência, com alguma interferência de uma nervosa violência que, já que éramos uma geração auto-complacente e auto-irônica com boas intenções, tentamos isolar como "terrorismo". Justo quando a Guerra Fria parecia estar pronta para se transformar numa completa "coexistência pacífica", a implosão do socialismo de Estado, em 1989, pegou nossa boa vontade de surpresa e nos obrigou a reconhecer que a linha de chegada da Guerra Fria se movera ainda mais uma vez. Como Vladimir e Estragon, nós nos movemos o tempo todo sem fazer qualquer progresso real. O pós-Guerra pareceu não ter fim.

Hoje (estou escrevendo estas linhas em Paris, por motivos aleatórios, em 20 de março de 2010), minhas questões são se será alguma vez possível traçar uma linha que definitivamente nos distanciará do pós-Segunda Guerra Mundial e se essa dificuldade é específica, ou apenas um problema geral com o qual qualquer cultura ou qualquer época são confrontadas quando tentam deixar seu passado para trás. Nós estamos tão inteiramente acostumados com isso, mas é notável que haja mais do que apenas traços deixados pela Segunda Guerra Mundial, sessenta e cinco anos após a rendição incondicional das forças do Eixo. A Rússia e a República Popular da China, por exemplo, não são mais efetivamente comunistas, mas ainda são "o outro" do bloco ocidental. Se os Estados Unidos da América nunca conseguiram realmente aprender a desempenhar o papel de poder hegemônico que eles assumiram durante os anos finais da Guerra, eles estão agora lutando para ir além desse status que nunca realmente abraçaram. Historiadores e generais franceses ainda estão debatendo de que forma seus museus e lugares de memória ("lieux de mémoire") devem encenar e narrar os anos entre 1940 e 1945 para suas gerações mais jovens e turistas de todo o mundo. E enquanto parece haver bem poucos fatos ainda para se desenterrar acerca do Holocausto, como o momento de mais extremo autoobscurecimento da humanidade, um filme como Bastardos Inglórios, de Quentin Tarantino, ainda pode dar a milhões de pessoas noites indormidas, enquanto as obriga a pensar se compreensão, perdão e reconciliação jamais serão suficientes para deixar esse passado para trás de nossas vidas e das vidas de nossos filhos e netos. Algo a respeito desse passado não descansa e tudo começa com a impossibilidade de apontar o que isso pode ser.

Não há soluções finais para esses problemas e, mesmo que eu fosse mais otimista, provavelmente não tentaria confrontar tal tarefa em meu livro - simplesmente porque sei que não sou bom nos gêneros "edificantes" ou "morais" de escrita intelectual. O ponto de partida é muito mais pessoal. Na medida em que o nascimento recente de dois netos me lembrou que minha vida está entrando em seu estágio final, o estágio da "velhice" (e não creio que haja qualquer coisa dramática a respeito disso), quero ver de que forma algumas premissas básicas da condição humana podem ter mudado (ou não), no intervalo de tempo entre meu nascimento e o presente - "atrás de mim", por assim dizer - e como elas podem ter mudado enquanto eu estava ocupado fazendo uma carreira acadêmica, criando uma família, viajando, escrevendo, confiando e traindo outras pessoas, mantendo e rompendo amizades, aproveitando a vida e, às vezes, me assustando bastante com ela. Ao buscar essa questão bastante pessoal e, logo, bastante estreita, que abre, ao mesmo tempo, um horizonte temático tão grande quanto se pode imaginar, quero enfocar uma estrutura específica e especificamente complexa de perspectivas, formas de percepção e, talvez, até mesmo obsessões, tal como tomavam forma entre os anos do imediato pós-Guerra e a metade ou o final da década de 1950 - e, surpreendentemente, não apenas em sociedades e culturas que participaram da Guerra.

Pois, acredito - ou, em palavras mais neutras: é esta a minha hipótese de trabalho - que essa configuração de condições manteve latente, até o presente momento, o que rapidamente desapareceu, como um impacto irreversível de destruição, durante os anos do pós-Guerra. Há três pares de motivos sobre os quais eu quero me concentrar: a dupla paradoxal formada pela impressão (claustrofóbica) de não existir saída e o medo (claustrofílico) de não existir entrada; uma preocupação crescente com a "má fé" e uma avidez por inventar métodos e configurações que "forçariam a sinceridade e extrairiam a verda- 
de"; e, finalmente, o desejo de proteção por meio de muros ou "containers" tridimensionais como opostos ao medo de "descarrilhar" dos caminhos em direção à felicidade e ao contentamento prometidos. O duplo argumento que quero provar é o de que esta configuração sêxtupla foi específica, em sua origem, à época do pós-Guerra e que seu impacto contido ainda pode ser sentido no presente.

\title{
Tradução: Pedro Telles da Silveira Revisão técnica: Carlos Fico
}

\author{
Notas \\ ${ }^{1}$ O subtítulo do diário alemão Süddeutsche Zeitung (“Jornal do Sul da Alemanha”) indica suas seçôes: notícias de Munique \\ de política, cultura, economia e esporte. Nota do Tradutor. \\ ${ }^{2}$ Literalmente, "luz lateral". A expressão designa uma seção de notícias incidentais. Nota do Tradutor. \\ ${ }^{3}$ Freibank era o local onde esse tipo de carne podia ser vendida. Nota do Tradutor. \\ 4 "A mudança". Nota do Tradutor. \\ 5 "Ela frequenta células existencialistas".
}

\section{RESUMO}

Proponho, neste artigo, o conceito de latência para a compreensão da experiência histórica, nos anos imediatamente posteriores ao fim da II Guerra Mundial. Para recuperá-la, analiso fotografias, cartōes postais, anúncios, artigos de jornais, textos ficcionais e não ficcionais, memórias pessoais, entre outros. A leitura destas fontes possibilita pensar que, pelo menos desde o fim da guerra, se anunciava um "clima" (stimmung) de latência, isto é, a impressão de que algo intangivel estava presente e que conformava o momento histórico. Minha hipótese é que essa transformação na construção social do tempo, implicando uma nova temporalidade, ainda permanece nas culturas ocidentais, neste início do século XXI. Palavras-chave: pós-1945; ressonâncias da guerra; temporalidade; latência.

\begin{abstract}
In this article, I propose the concept of latency for the understanding of historical experience in the years immediately after the end of World War II. In order to recover it, I analyze photographs, postcards, ads, newspaper articles, fictional and non-fictional texts, personal memories, among others. Reading these documentary sources it is possible to think that, at least since the end of the war, there were signs of the latency "atmosphere" (stimmung), that is, the impression that something intangible was present and that it conformed the historical moment. My hypothesis is that this transformation in the social construction of time, implying a new temporality, still exists in western cultures now, in the beginning of the 21st century.

Keywords: post-1945; echoes of war; temporality; latency.
\end{abstract}

